\title{
EFFECT OF SINTERING ON THE STRENGTH OF IRON-BASED POWDER COMPOSITES
}

\author{
P. A. Polyakov ${ }^{1}$, A. V. Dolmatov ${ }^{2}$, V. L. Kolmykov ${ }^{1}$, \\ O. V. Romanova ${ }^{2}$, M. N. Zakharov ${ }^{2}$ \\ ${ }^{l}$ Institute of Engineering Science, Ural Branch of the Russian Academy of Sciences, \\ 34 Komsomolskaya St., Ekaterinburg, Russian Federation \\ ${ }^{2}$ Institute of Metallurgy, Ural branch of the Russian Academy of Sciences, \\ 101 Amundsena St., Ekaterinburg, Russian Federation \\ *Corresponding author. E-mail: pavel.katsu@gmail.com; \\ address for correspondence: 34, ul. Komsomolskaya, 620049, Ekaterinburg, Russian Federation. \\ Tel.: +7 (343) 37450 51; fax: +7 (343) 3745330 \\ The effect of sintering on the mechanical properties of iron-based vanadium-containing \\ powders with various additives is studied. The results of uniaxial compression testing show that \\ specimens made of the powder without additives and compositions with zinc or copper change their \\ shape from cylindrical to barrel-type with increasing pressure, whereas less dense powder speci- \\ mens with phosphorus collapse. The cylindrical shape of specimens with graphite as an additive \\ remains unchanged. After sintering, the Brinell hardness for the iron powder without additives and \\ the compositions with zinc or copper decreases, and it increases for the powders with phosphorus \\ and those with graphite, particularly for the composition with graphite. Sintered briquettes with \\ graphite have much higher values of Brinell hardness and compressive strength than the other com- \\ positions. The compressive yield strength of the investigated billets has been determined.
}

Keywords: strength, Brinell hardness, sintering, iron powder, compression testing.

DOI: $10.17804 / 2410-9908.2017 .1 .013-023$

\section{References}

1. Metally i splavy. Spravochnik [Metals and Alloys. Reference Book, ed. Yu.P. Solntsev]. St. Petersburg, Professional, 2003, 1062 p. (In Russian).

2. Material and Powder Properties. Höganäs Handbook for Sintered Components, Höganäs AB, Sweden, 2013.

3. Andrievsky R.A. Poroshkovoe materialovedenie [Powder Material Science]. M., Metallurgiya, 1991, 205 p. (In Russian).

4. Roman O.V., Gabrielov I.P. Spravochnik po poroshkovoi metallurgii: poroshki, materialy, protsessy [Handbook of Powder Metallurgy: Powders, Materials, Processes]. Minsk, Belarus, 1988, 175 p. (In Russian).

5. Fedorchenko I.M., Frantsevich I.D., Radomyselsky I.D., Kovalchenko M.S. Poroshkovaya metallurgiya: materialy, svoiystva, oblast primeneniya. Spravochnik [Powder metallurgy. Materials, Properties, Application. Reference Book]. Kiev, Naukova Dumka, 1985, 624 p. (In Russian).

6. Polyakov P.A., Kolmykov V.L., Polyakov A.P. A study of extrusion of composite materials based on vanadium-containing iron powder. Kuznechnoshtampovochnoe proizvodstvo. Obrabotka metallov davleniem, 2013, no. 5, pp. 14-18. (In Russian).

7. Zalazinsky G.G., Shchennikova T.L., Zalazinsky G.G. (Jr.), Mitrofanov V.Ya. The properties of powder mixtures and materials based on iron with the addition of iron-phosphorus powder. Perspektivnye Materialy, 2013, no. 10, pp. 41-46. (In Russian).

8. Savintsev P.P., Ryabova R.F. Effect of the particle size of pulverized iron powders and molding pressure on the properties of powder materials. Fizika i khimiya obrabotki materialov, 2004, no. 2, pp. 78-83. (In Russian). 
9. Chaurasia S.K., Prakash U., Misra P.S., Chandra K. Development of P/M Fe-P soft magnetic materials. Bull. Mater. Sci., 2012, vol. 35, no. 2, pp. 191-196. DOI: 10.1007/s12034-012-0272-z.

10. Oglezneva S.A., Mikhailov A.O., Zubko I.Y. Influence of Carbon on the Formation of Structure during Mechanical Alloying and Sintering of Powder Steels. Russian Journal of Nonferrous Metals, 2008, vol. 49, no. 4, pp. 283-289. DOI: 10.3103/S1067821208040147. 
Подана в журнал: 03.02.2017

УДК 621.762

DOI: $10.17804 / 2410-9908.2017 .1 .013-023$

\title{
ВЛИЯНИЕ СПЕКАНИЯ НА ПРОЧНОСТЬ ПОРОШКОВЫХ КОМПОЗИЦИЙ НА ОСНОВЕ ЖЕЛЕЗА
}

\author{
П. А. Поляков ${ }^{1} *$, А. В. Долматов ${ }^{2}$, В. Л. Колмыков ${ }^{1}$, \\ О. В. Романова ${ }^{2}$, М. Н. Захаров ${ }^{2}$ \\ ${ }^{1}$ Федеральное государственное бюджетное учреждение науки Институт машиноведения \\ Уральского отделения Российской академии наук, ул. Комсомольская, 34, \\ Екатеринбург, Российская Федерация \\ ${ }^{2}$ Федеральное государственное бюджетное учреждение науки Институт металлургии \\ Уральского отделения Российской академии наук, ул. Амундсена, д. 101, \\ Екатеринбург, Российская Федерациия \\ *Ответственный автор. Электронная почта: pavel.katsu@gmail.com; \\ адрес для переписки ул. Комсомольская, 34, 620049, Екатеринбург, Российская Федерация. \\ Телефон: +7 (343) 374-50-51; факс: +7 (343) 374-53-30
}

Исследовано влияние спекания на прочностные свойства образцов из ванадийсодержащего порошка железа с различными добавками. По результатам испытаний на осевое сжатие показано, что образцы из исходного порошка, составов с добавкой цинка или меди с ростом давления меняли форму с цилиндрической на бочкообразную, менее плотные образцы из порошка с фосфором разрушились. Образцы из порошка с графитом в процессе нагружения не меняли цилиндрическую форму. После спекания твердость по Бринеллю для исходного порошка железа, составов с добавкой цинка или меди уменьшается, для порошков с фосфором и графитом, наоборот, увеличивается, особенно для состава с графитом. Брикеты с добавкой графита после спекания характеризуются гораздо более высокими значениями твердости по Бринеллю и прочностью на сжатие по сравнению с остальными составами. Определен предел текучести при сжатии исследованных образцов.

Ключевые слова: прочность, твердость по Бринеллю, спекание, порошок железа, испьтание на сжатие.

\section{1. Введение}

В связи с низкой прочностью и твердостью спеченного железа для повышения его механических свойств в железный порошок при приготовлении смеси вводят легирующие добавки (фосфор, медь, хром и др.), спеченные изделия подвергают химико-термической обработке. Также порошки на основе железа часто легируются углеродом в виде графита, сажи или чугунного порошка, в результате спеченное железо приобретает способность закаливаться, значительно повышается его твердость и прочность [1]. Наиболее распространен метод введения в порошковую смесь графита. Повышение прочности спеченных образцов на основе железа с добавками меди, цинка, фосфора, углерода отмечено в [2]. Порошки железа, легированные фосфором, являются основой для магнитомягких материалов $[3,4,5]$, которые в основном закупаются за рубежом (фирма-производитель Hüganäs AB) [2]. Одним из отраслевых потребителей порошковой металлопродукции является автомобилбная промышленность. Так, европейский автомобиль содержит в среднем 7,5 кг деталей из металлических порошков, североамериканский - 16 кг. Прирост веса металлопорошковых деталей в автомобилях прогнозируется на уровне 3,7 \% в год.

Для исследований выбраны порошковые композиции, полученные механической активацией ванадийсодержащих порошков железа в смеси с $\mathrm{Zn}, \mathrm{Cu}, \mathrm{Fe}-\mathrm{P}, \mathrm{C}$ в количестве 
1,5 мас. \% на измельчителе вибрационном ИВ-микро. Шихты на основе порошка железного были получены в институте металлургии УрО РАН и имели следующий химический состав, мас. \%: 0,027 C; 0,160 Si; 0,144 Mn; 0,266 V; 0,530 $\mathrm{O}_{2}$; Fe - основа. Порошок железо-фосфор имел следующий химический состав, мас. \%: 25,0 P; 4,1 Si; 6,1 Mn; Fe - основа.

Данные о гранулометрическом составе и морфологических свойствах исходных порошков получены на анализаторе частиц по размерам и форме CAMSIZER-XT в институте металлургии (ИМЕТ) УрО РАН (для анализа графита использован прибор Horiba) и приведены в табл. 1.

Таблица 1 - Данные о гранулометрическом составе и морфологии порошков

\begin{tabular}{|l|c|c|c|c|}
\hline \multicolumn{1}{|c|}{ Порошок } & $d_{\text {cp }}$, мкм & $S P H T_{\mathrm{cp}}$ & $S y m m_{\mathrm{cp}}$ & $b / l_{\text {cp }}$ \\
\hline Железо (фракция менее 315 мкм) & 142 & 0,616 & 0,843 & 0,700 \\
\hline Железо (фракция менее 160 мкм) & 108 & 0,571 & 0,859 & 0,712 \\
\hline Медь электролитическая & 39,6 & 0,600 & 0,867 & 0,664 \\
\hline Цинк распыленный & 9,5 & 0,847 & 0,887 & 0,747 \\
\hline Железо-фосфор распыленный & 24,1 & 0,747 & 0,893 & 0,733 \\
\hline Графит карандашный & 44,9 & - & - & - \\
\hline
\end{tabular}

Примечание. $d_{\text {ср }}$, мкм - медианный диаметр (размер частиц менее 50 \% пробы);

$S P H T_{\mathrm{cp}}-$ среднее значение коэффициента сферичности частиц;

$S y m m_{\mathrm{cp}}$ - среднее значение коэффициента симметричности частиц;

$b / l_{\mathrm{cp}}-$ среднее значение соотношения ширины и длины частиц.

\section{2. Постановка задачи}

Образцы для исследования прочностных характеристик изготовлены на оборудовании ЦКП «Пластометрия» ИМАШ УрО РАН, на универсальной гидравлической машине Tinius Olsen Super L60, имеющей следующие характеристики: максимальное усилие $300 \mathrm{\kappa H}$; размеры рабочей зоны: высота - 737 мм, ширина - 356 мм; скорость подвижной траверсы от 0 до 76 мм/мин.

Навески порошка массой 8 г брикетировали односторонним прессованием в пресс-форме диаметром 9,6 мм при комнатной температуре и при давлении прессования 600-700-800 МПа. Получены брикеты высотой $17-18$ мм с относительной плотностью $\rho_{\text {отн }} \approx 0,77 \div 0,91$. Плотность образцов определяли по стандартной методике (ГОСТ 18898-89). Относительную плотность $\rho_{\text {отн }}$ определяли как отношение фактической плотности прессовок к теоретической, которую вычисляли исходя из состава порошковой композиции по правилу смесей. Спекание проводили в вакууме $10^{-3}$ МПа в вакуумной электропечи сопротивления камерного типа СНВЭ-2.4.2/16И2 в ИМЕТ УрО РАН по режиму: нагрев в течение 1 ч, выдержка при температуре $1150{ }^{\circ} \mathrm{C}$ в течение 2 часов, охлаждение с печью до температуры $200{ }^{\circ} \mathrm{C}$. Обозначим прессовки следующим образом: П1 - исходный железный порошок; П2 - Fe + 1,5\% Zn; П3 - Fe + 1,5\% Cu; П4 - Fe + 1,5\% (Fe-P); П5 - Fe + 1,5 \% C.

На рис. 1 представлены результаты испытаний неспеченных брикетов на осевое сжатие. При осевом сжатии напряжение, при котором в образце возникает трещина, определяется по формуле:

$$
\sigma_{\text {сж }}=4 P / \pi D^{2},
$$

где $P$ - усилие к моменту начала разрушения образца; $D$ - диаметр образца. 


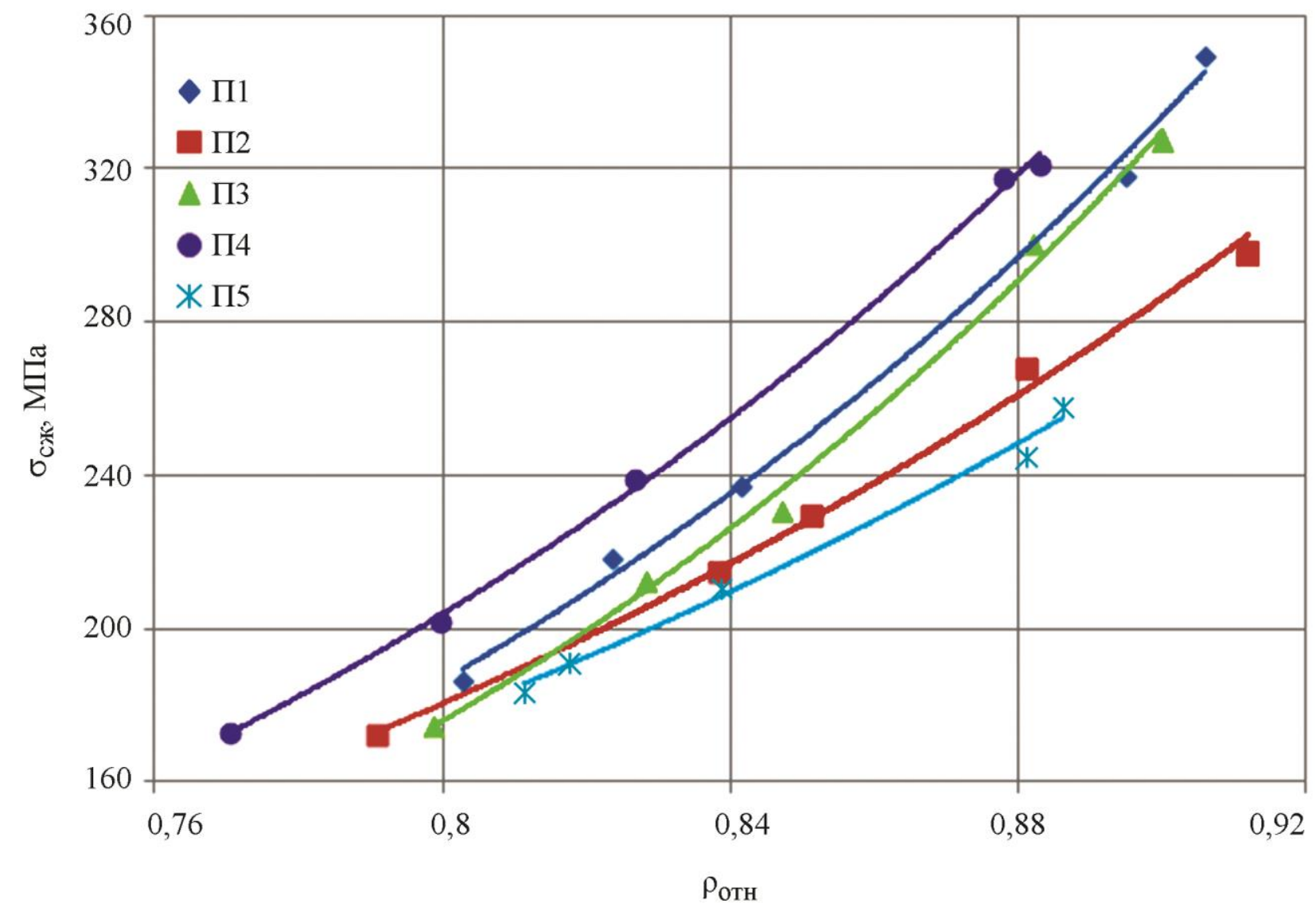

Рис. 1. Зависимость напряжения при возникновении трещины от плотности при осевом сжатии

Видим, что наибольшей прочностью при осевом сжатии обладает порошок П4 (с фосфором). Несколько менее прочными являются исходный порошок (П1) и порошок с добавкой меди (П3). Что касается порошков с добавкой цинка и графита (П2 и П5), при плотности $\rho_{\text {отн }} \approx 0,8 \div 0,82$ их прочность при осевом сжатии незначительно отличается от прочности

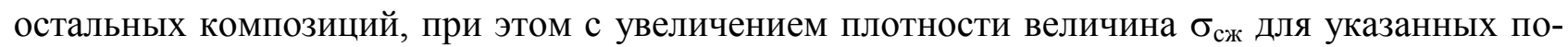
рошков растет медленнее, чем для П1, П3 и П4.

Исследования прочности на сжатие спеченных образцов различной плотности выполнены на прессовках различной плотности на машине BT1-FR050THW/A1K (ЦКП «Урал-М», ИМЕТ), возможное максимальное усилие $50 \mathrm{\kappa H}$, ход траверсы не более 7,5-8,0 мм. Процесс прекращался при достижении хотя бы одним из указанных показателей предельного значения. Зависимости усилие-перемещение траверсы для образцов различной плотности показаны на рис. 2. Для образцов из составов П1-П3 процесс заканчивался при достижении предельного перемещения траверсы. Для образцов из порошка П5, а также образцов из порошка П4 с максимальной плотностью процесс прекращался при достижении максимальной нагрузки, при этом перемещение траверсы составляло около 2 мм (рис. 2). 


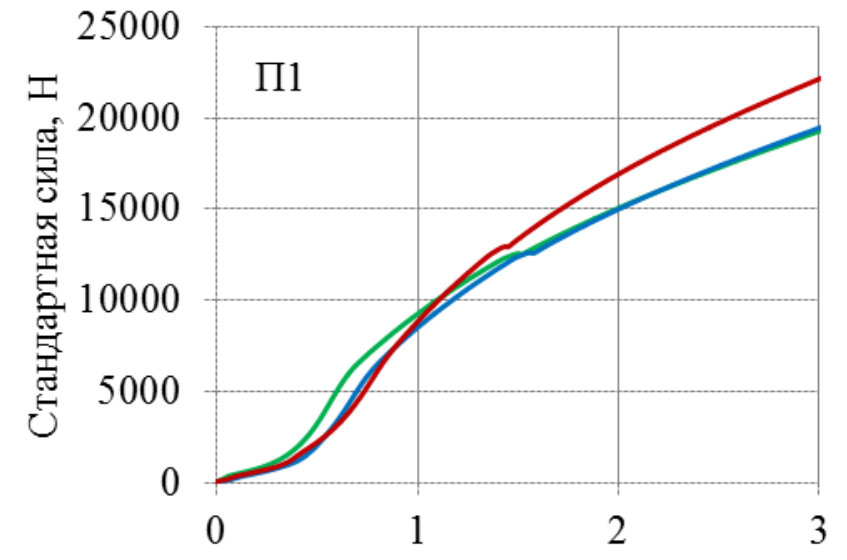

Перемещение, мм

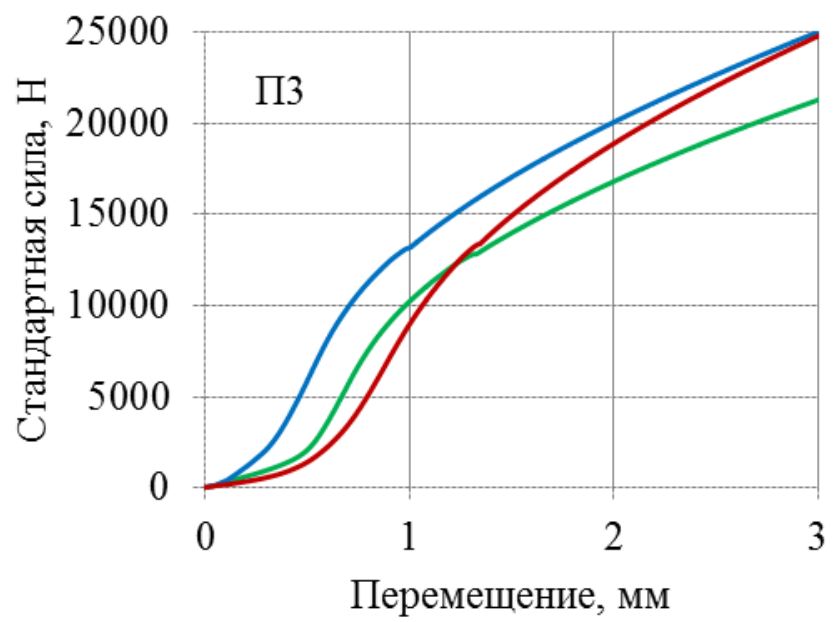

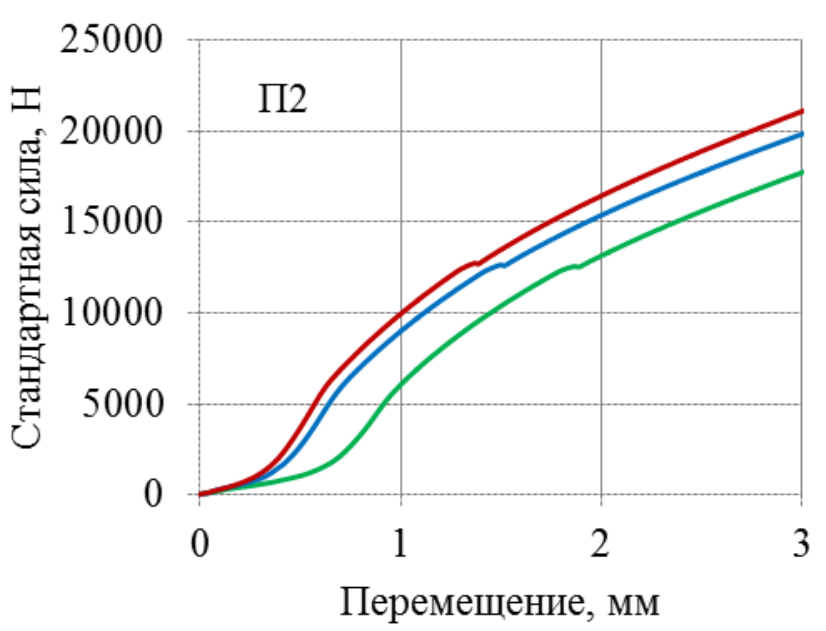

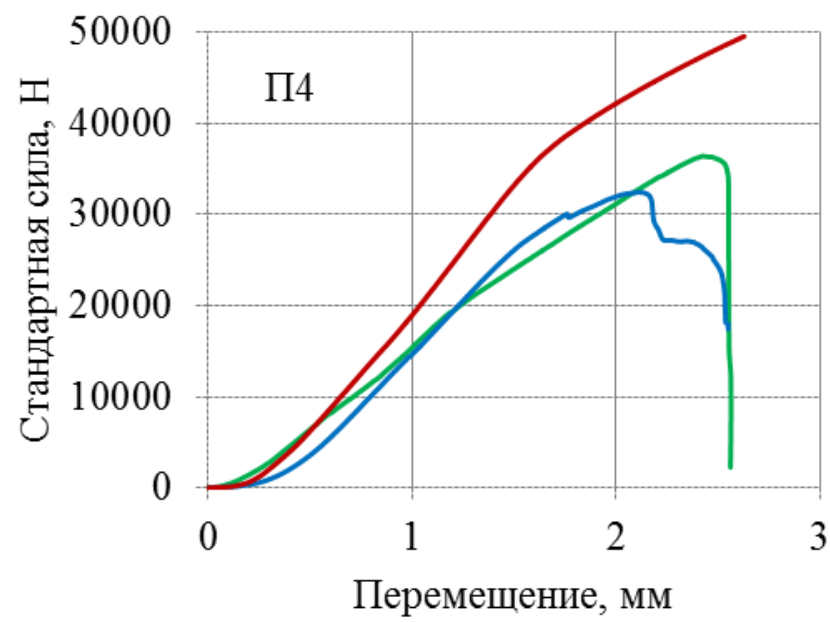

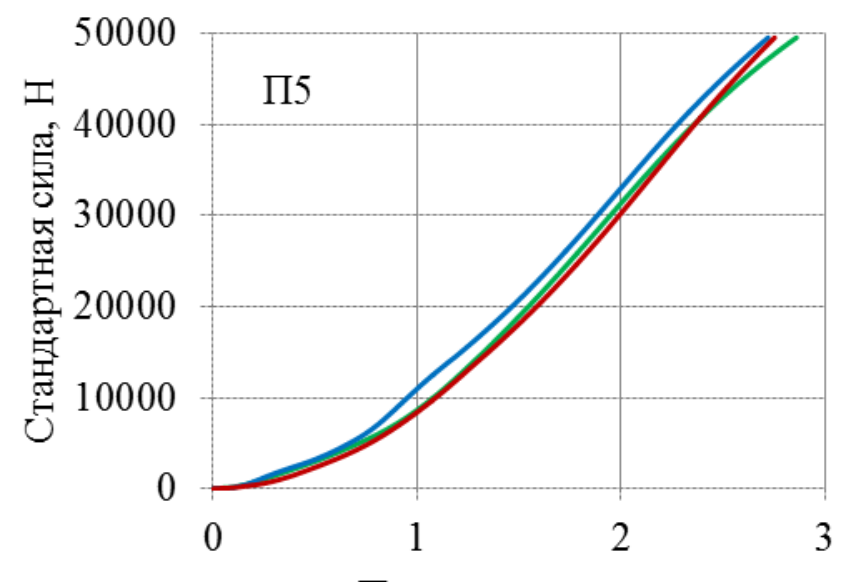

Перемещение, мм

Рис. 2. Зависимости усилие-перемещение траверсы при осевом сжатии спеченных брикетов (по составам). Зеленая кривая соответствует образцам, изготовленным при давлении 600 МПа, синяя кривая - 700 МПа, красная кривая - 800 МПа

\section{3. Обсуждение результатов}

Образцы из порошков П1-П3 с ростом давления меняли форму с цилиндрической на бочкообразную (рис. 3). Менее плотные образцы из порошка П4 (с фосфором) разрушились 
(рис. 2). При этом образцы из порошка П5 (с графитом) в процессе нагружения практически не меняли цилиндрическую форму независимо от исходной плотности.

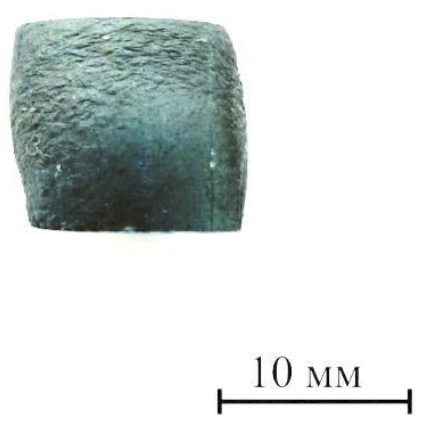

Рис. 3. Спеченный образец из порошка П3 после сжатия

Интерес представляют данные по пределу текучести $\sigma_{0,2}$, представленные на рис. 4. Видим, что наименьшие значения $\sigma_{0,2}$ получены для порошка П2 (с цинком). При этом для порошка П5 с увеличением плотности даже при максимальном усилии 50 кН пластическая деформация не достигала уровня 0,2 \%, и ее невозможно было зафиксировать (поэтому на рис. 4 только одна экспериментальная точка). В данном случае образцы деформировались практически только упруго. В то же время образцы из порошка П4 (с фосфором), имея гораздо более высокое значение $\sigma_{0,2}$ по сравнению с порошками П1-П3 (рис. 4), частично разрушились. Вероятно, это связано с тем, что и после спекания этот состав являлся менее пластичным по сравнению с порошками П1-П3. в табл. 2.

Коэффициенты аппроксимации для формулы $\sigma_{0,2}=K \cdot \exp \left(m \rho_{\text {отн }}\right)$ представлены

Таблица 2 - Коэффициенты для расчета $\sigma_{0,2}$ спеченных брикетов

\begin{tabular}{|c|c|c|c|}
\hline Порошок & $\kappa$, МПа & $m$ & $R^{2}$ \\
\hline$\Pi 1$ & 0,0833 & 8,878 & 0,996 \\
\hline$\Pi 2$ & 34,685 & 1,472 & 0,938 \\
\hline$\Pi 3$ & 5,899 & 4,045 & 0,973 \\
\hline$\Pi 4$ & 9,614 & 4,886 & 0,913 \\
\hline
\end{tabular}




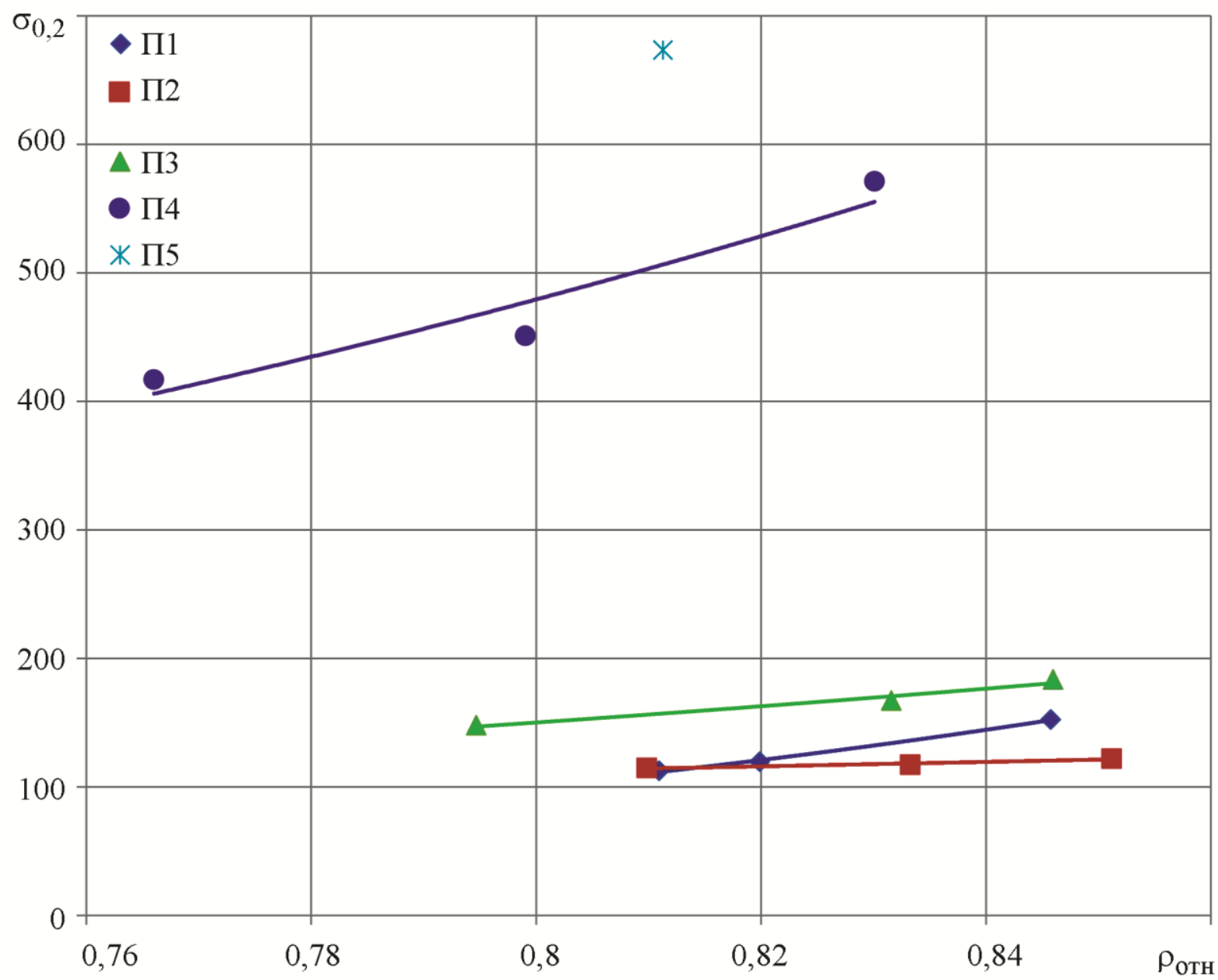

Рис. 4. Зависимость $\sigma_{0,2}$ спеченных прессовок от плотности

При анализе результатов измерения твердости учтено, что плотность по высоте брикета (а значит и твердость) распределена неравномерно [6], поэтому рассматривали средние величины между значениями НВ для верхней и нижней части брикета (отклонение крайних значений от среднего в пределах $5 \%$ ). На рис. 5 представлены результаты измерений величины НВ для исследованных образцов до спекания. Показано, что максимальные значения НВ получаются для порошка П4, минимальны для порошка П5 (примерно до уровня $\rho_{\text {отн }}<0,88$ ).

После спекания величина НВ для всех исследованных композиций меняется (рис. 6). Для составов П1-П3 видим уменьшение твердости после спекания, тогда как для составов П4 и П5, наоборот, ее увеличение, причем существенное, особенно для состава П5 (рис. 5 и 6). Заметим, что максимальное усилие при испытаниях на машине BT1-FR050THW/A1K, paвное 50 кН, для исследованных образцов соответствует давлению порядка $700 \mathrm{MПа,} \mathrm{что} \mathrm{говорит}$ о высоком уровне сопротивления сжатию исследованных композиций. 


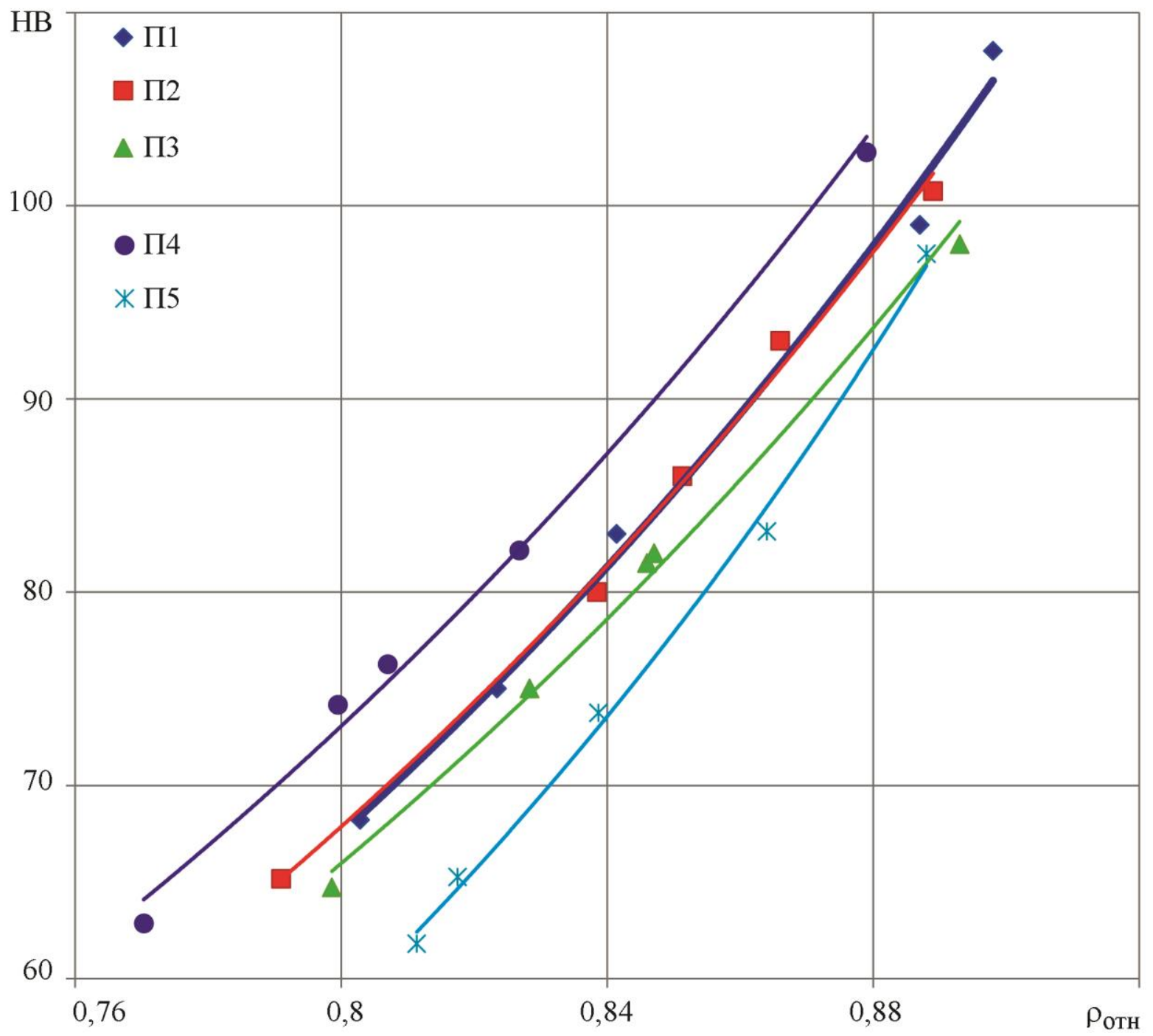

Рис. 5. Зависимость твердости НВ от плотности брикетов до спекания

Коэффициенты для расчета НВ по формуле $\mathrm{HB}=K \cdot \exp \left(m \rho_{\text {отн }}\right)$ представлены в табл. 3.

Таблица 3 - Коэффициенты для расчета НВ спеченных брикетов

\begin{tabular}{|c|c|c|c|}
\hline Порошок & $K$ & $m$ & $R^{2}$ \\
\hline$\Pi 1$ & 2,5588 & 3,836 & 0,960 \\
\hline$\Pi 2$ & 10,319 & 2,041 & 0,999 \\
\hline$\Pi 3$ & 10,205 & 2,392 & 0,993 \\
\hline$\Pi 4$ & 119,3 & 0,742 & 0,982 \\
\hline$\Pi 5$ & $3 \cdot 10^{-6}$ & 21,67 & 0,999 \\
\hline
\end{tabular}




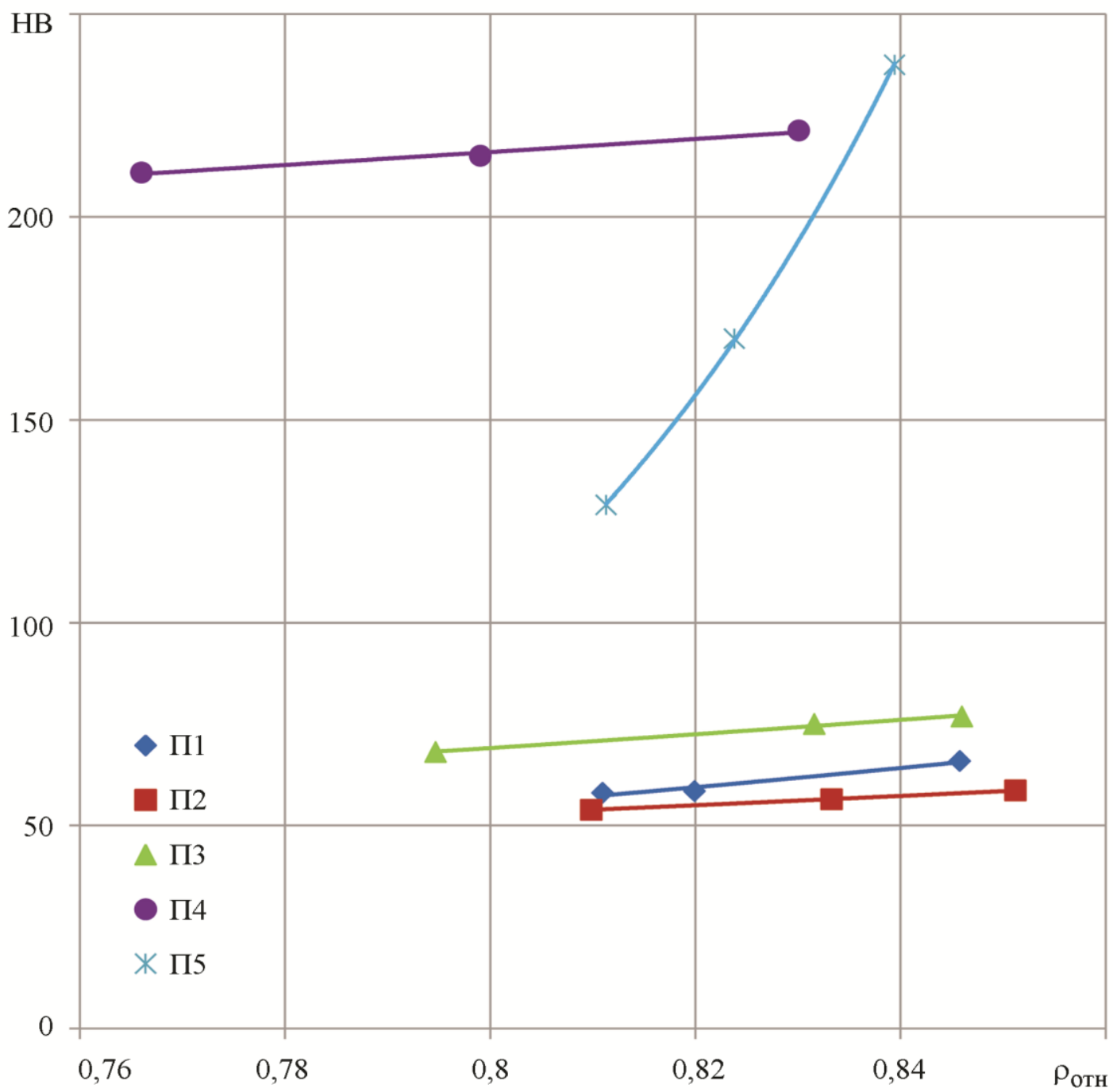

Рис. 6. Зависимость твердости НВ от плотности прессовок после спекания

В целом результаты, представленные на рис. 5 и 6, качественно коррелируют с экспериментальными данными из литературы. Количественное сравнение в данном случае затруднительно ввиду различия состава материалов, рассмотренных в статье и исследованных другими авторами.

Так, согласно данным работы [8] твердость НВ прессовок из монофракционных порошков железа после спекания уменьшается. Это, по мнению авторов, обусловлено снижением напряжений и рекристаллизацией. В соответствии с работой [9] при изменении содержания фосфора в порошке железа с 0,3 \% до 0,8 \% твердость НВ увеличивается примерно на 20 \% после горячего прессования или после горячей прокатки с последующим отжигом [7]. Значительное увеличение твердости НВ после спекания при добавлении к порошку железа углерода отмечается в работе [4]. В работе [10] приведены зависимости в железном порошке твердости НВ для спеченных образцов из порошка ПЖРВ в зависимости от добавки углерода 0,5-2 \%. Причем зависимость немонотонна, максимальное значение достигается при содержании углерода $1 \%$.

\section{4. Выводы}

1. Экспериментально исследован процесс прессования и выполнена оценка изменения прочностных свойств образцов из ванадийсодержащих порошков железа с добавками $\mathrm{Zn}, \mathrm{Cu}, \mathrm{Fe}-\mathrm{P}, \mathrm{C}$ в количестве 1,5 мас. \% после спекания. 
2. По результатам испытаний, неспеченных прессовок на осевое сжатие наиболее прочными являются брикеты из порошка железо-фосфор, наименее - из порошка с графитом. Испытания на осевое сжатие спеченных образцов при максимальной нагрузке 50 кН показали, что образцы из исходного порошка, составов с добавкой цинка или меди с ростом давления меняли форму с цилиндрической на бочкообразную. Менее плотные образцы из порошка с фосфором разрушились. При этом образцы из порошка с графитом в процессе нагружения практически не меняли цилиндрическую форму независимо от исходной плотности.

3. Максимальная твердость по Бринеллю для неспеченных прессовок достигается для порошка с фосфором, а минимальная - для порошка с графитом. После спекания величина НВ для исходного порошка, составов с добавкой цинка или меди уменьшается, тогда как для порошков с фосфором и с графитом, наоборот, увеличивается, причем существенно, особенно для состава с графитом. Брикеты с добавкой графита после спекания характеризуются гораздо более высокими значениями твердости по Бринеллю и прочностью на сжатие по сравнению с остальными составами.

4. Определен предел текучести $\sigma_{0,2}$ при сжатии. Наименьшие значения получены для порошка с цинком. Для состава с графитом при максимальном усилии 50 кН пластическая деформация не достигала уровня 0,2 \%, ее невозможно было зафиксировать, образцы деформировались практически только упруго. При этом образцы из порошка с железо-фосфором, имея гораздо более высокое значение $\sigma_{0,2}$ по сравнению с образцами из исходного порошка и составов с добавками меди и цинка, частично разрушились.

\section{Литература}

1. Металлы и сплавы : справочник / под ред. Ю. П. Солнцева. - СПб. : Профессионал, 2003. - $1062 \mathrm{c}$.

2. Material and Powder Properties. Höganäs Handbook for Sintered Components. - Höganäs AB, Sweden, 2013.

3. Андриевский Р. А. Порошковое материаловедение. - М. : Металлургия, 1991. - 205 с.

4. Роман О. В., Габриелов И. П. Справочник по порошковой металлургии: порошки, материалы, процессы. - Минск : Беларусь, 1988. - 175 с.

5. Порошковая металлургия: материалы, технология, свойства, область применения : справочник / И. М. Федорченко, И. Н. Францевич, И. Д. Радомысельский, М. С. Ковальченко. Киев : Наукова думка, 1985. - 624 с.

6. Поляков П. А., Колмыков В. Л., Поляков А. П. Исследование процесса прессования композиционных материалов на основе ванадийсодержащего порошка железа // КШП. ОМД. 2013. - № 5. - С. 14-18.

7. Свойства порошковых смесей и материалов на основе железа с добавкой порошка железо-фосфор / Г. Г. Залазинский, Т. Л. Щенникова, Г. Г. Залазинский (мл.), В. Я. Митрофанов // Перспективные материалы. - 2013. - № 10. - С. 41-46.

8. Савинцев П. П., Рябова Р. Ф. Влияние размера частиц распыленных железных порошков и давления формования на свойства порошковых материалов // Физика и химия обработки материалов. - 2004. - № 2. - С. 78-83.

9. Development of P/M Fe-P soft magnetic materials / S. K. Chaurasia, U. Prakash, P. S. Misra, K. Chandra // Bull. Mater. Sci. - 2012. - Vol. 35, no 2. - P. 191-196. DOI: $10.1007 / \mathrm{s} 12034-012-0272-\mathrm{z}$.

10. Oglezneva S. A., Mikhailov A. O., Zubko I. Y. Influence of Carbon on the Formation of Structure during Mechanical Alloying and Sintering of Powder Steels // Russian Journal of Non-ferrous Metals. - 2008. - Vol. 49, no. 4. - P. 283-289. - DOI: 10.3103/S1067821208040147 